\title{
Economic and environmental performance of alternative policy measures to reduce nutrient surpluses in Finnish agriculture
}

\author{
Heikki Lehtonen \\ MTT Agrifood Research Finland, Economic Research, Luutnantintie 13, FI-00410 Helsinki, Finland \\ e-mail:heikki.lehtonen@mtt.fi \\ Jussi Lankoski \\ OECD, Trade and Agriculture Directorate, 2, rue Andre-Pascal, \\ 75775 Paris Cedex 16, France \\ Kauko Koikkalainen \\ MTT Agrifood Research Finland, Economic Research, Luutnantintie 13, FI-00410 Helsinki, Finland
}

This paper provides an economic sector level analysis of the effectiveness of different policy measures in decreasing nitrogen $(\mathrm{N})$ and phosphorus $(\mathrm{P})$ surpluses from agriculture in order to reduce nutrient runoff from agricultural fields to watercourses and to improve water quality of surface waters. Assuming no changes in the EU level policies after CAP reform 2003 we focus on national level policy measures such as full or partial de-coupling of national support from production, payments for reduced nutrient surpluses of $\mathrm{N}$ and $\mathrm{P}$, and $\mathrm{N}$ fertiliser tax.

None of the analysed policy measures is superior one with respect to environmental performance, since full decoupling of national support would be the most effective in reducing P surpluses while payment for reduced nutrient surplus performed best with respect to $\mathrm{N}$ surpluses. Economic performance (farmers' compliance cost per \%-reduction of $\mathrm{N}$ or $\mathrm{P}$ surplus) of full and partial de-coupling of national support is clearly better than that of specialised agri-environmental policy instruments, because both decoupling scenarios result in the increase of farmers' income in comparison to base scenario, and thus compliance costs are in fact negative in these two cases.

Our analysis confirms the fact that the overall policy package matters a lot for the effectiveness of agrienvironmental policy measures. Environmental performance of agri-environmental policy measures may be significantly reduced, if they are implemented jointly with production coupled income support policies. Thus, in order to increase the effectiveness of agri-environmental policy measures agricultural income support policies should be decoupled from production and this alone would bring substantial reduction in nutrient surpluses.

Key-words: agri-environmental policy, nutrient surplus, agricultural economics, agricultural sector modelling, nitrogen, phosphorus 


\section{Lehtonen et al. Economic and environmental performance of policy measures}

\section{Introduction}

Nutrients, chiefly nitrogen $(\mathrm{N})$, phosphorus $(\mathrm{P})$, and potassium $(\mathrm{K})$, are important inputs in agricultural production. Of the three main nutrients, $\mathrm{N}$ and $\mathrm{P}$ may cause water quality problems in surface water and groundwater. Nutrient runoff from agriculture is typical non-point source pollution, since the runoff does not emanate from a single point except in the case of drainage but from so many places that an accurate monitoring of each source would be prohibitively expensive (Ribaudo et al. 1999). Thus, in the case of agricultural non-point source pollution standard solutions for point source pollution, such as effluent standards and effluent taxes, cannot be applied directly, since pollution flows from non-point sources cannot be monitored with reasonable accuracy or at reasonable cost (Shortle and Dunn, 1986). When nutrient runoff cannot be addressed directly because of the non-point features of agricultural pollution, the policy maker/regulator is forced to use indirect instruments or emissions proxies. For example, alternative instrument bases can be the use of polluting inputs, such as chemical fertilizer, manure or pesticides, or more sophisticated emission proxies, such as excess or surplus nutrients, which are estimated on the basis of nutrient balance calculations. The economic theory on the design of agricultural nutrient pollution control started by Griffin and Bromley (1982). Subsequent influential contributions were made by Shortle and Dunn (1986) and Segerson (1988).

Although the economic theory of agricultural nutrient pollution control is well developed there is quite a limited experience with actual implementation of the proposed policy instruments, such as fertilizer taxes or nutrient surplus instruments. Although fertilizer taxes (including both $\mathrm{N}$ and $\mathrm{P}$ based taxes) have been implemented in some OECD countries, those taxes have usually been levied at such a low rates that their impact on fertilizer use intensity has been quite moderate. Moreover, experience from nutrient surplus based instruments has been very limited to date. In fact, most OECD member countries have mainly relied on voluntary agri-environmental payment programs to reduce agricultural nutrient runoff into watercourses. The obvious problem with these voluntary payment programs is that their environmental effectiveness may be significantly reduced because they are implemented in the context of environmentally distorting agricultural policies. Agricultural policies coupled to production may provide strong incentives to increase input use intensity of environmentally harmful inputs, such as fertilizers or pesticides, or they may drive land allocation towards more intensive crops or expand agriculture into environmentally sensitive areas. Such incentives may reinforce the environmental market failures in agriculture. Conventional policy design principle is that these policy failures should be removed first and then the remaining market failures should be addressed by targeted agrienvironmental policies.

In the case of Finland the sum of national production linked supports is higher than the EU CAP payments which were partially decoupled from production. The total sum of national subsidies was 611 million euros while the sum of all CAP payments was 541 million euros in 2006. These national supports, including payments per litre of milk, per head of different animals (bovines, pigs and poultry) and per hectares of specific crops, influence both the use of inputs and the scale of production. Such supports can be considered even more linked to production than the earlier Agenda 2000 payments (production effects of different forms of support was evaluated by Dewbre et al. 2001). Hence we consider the decoupling of national supports as a very relevant policy option and benchmark, especially since decoupling can be considered as a domestic choice. Moreover, decoupling of Finnish national supports from production would suit very well the interests of the European Commission at the WTO as well.

Improvement in surface water quality has been so far the main objective of agri-environmental policy in Finland (Valpasvuo-Jaatinen et al. 1997). The quality of surface waters can be linked to agricultural production through estimating surplus of nutrients, which provides an indicator of potential runoff of nutrients. It should be noted that actual 
Vol. 16 (2007): 421-440

nutrient runoff from a given parcel is only partly explained by estimated nutrient surplus in that parcel as there are many exogenous and stochastic factors which affect the amount of actual runoff including the weather, topography and soil characteristics (Salo and Turtola 2006, Rankinen et al. 2007).

Moreover, the relationship between nutrient surpluses and agricultural production is more complex than merely analysing individual farm management practices, such as fertilisation and crop yield levels for each crop. Changes in agricultural production may be linked to production specialisation, technological change and market feedback through prices. Hence, if analysis focus only on individual crops or production lines then it may be difficult to identify important cause-effect linkages. There has been considerable changes in agricultural production, including the changing agricultural management practices, the increased use of fertilizers and pesticides, the increase of sub-surface drainage and enlarged field parcels, as well as the reduction of wintertime plant cover on farmland in the last 30-40 year (Tiainen and Pakkala 2000, 2001; Tiainen et al. 2004) Since grasslands providing wintertime plant cover have diminished, it is widely recognised that changes in livestock production are very decisive in terms of farmland biodiversity and nutrient runoff (Pykälä 2000, Uusitalo et al. 2007). Hence, changes in nutrient runoff from agriculture seem to be linked to overall changes in agriculture.

Partial analyses focusing on individual production lines, which compete on the same regional land and labour resource, may not always provide a sound basis for policy recommendations. A sector level analysis, entailing the overall change in agriculture, is needed when evaluating potential to reduce nutrient runoff from agricultural sector. Since the national supports and agri-environmental payments are very significant in Finland we focus on the different options of these supports and their performance in decreasing nutrient balances. Our aim in this paper is to provide relevant material for the stakeholders responsible for the domestic design of agri-environmental policies in Finland. The aim is to show the relative impact of domestic policy choices while keeping EU level choices constant.
In order to do this, one needs to analyze:

1) How do alternative policy options affect the relative profitability of different production lines and how this affects the quantity and intensity of agricultural production and land use?

2) How do the $N$ and $P$ surpluses change as a result of changing production patterns and intensity of production?

3) How effective are specific agri-environmental policy measures, such as payment for reduced nutrient surplus or fertiliser tax in comparison to a partial or full decoupling of national support, in reducing nutrient surpluses from agricultural sector?

We examine these questions by simulating the production impacts of different policy measures using a dynamic regional sector model of Finnish agriculture (DREMFIA) (for a thorough description of the model see Lehtonen, 2001). In addition to analyses of production and income effects of agricultural policies, this model has been earlier employed to assess the effects of alternative EU level policy scenarios on the multifunctional role of Finnish agriculture. Earlier Lehtonen et al. (2005) evaluated four agricultural policy scenarios relevant at the European perspective: Agenda 2000, CAP Reform 2003, Integrated rural and environmental policy (INT), and liberalised agricultural trade (LIB). In the first two scenarios only CAP supports (comprising 30\% of farm subsidies paid in Finland) were varied while no changes were assumed in other forms of support; in national supports, LFA payments or in agri-environmental payments. In the INT scenario it was assumed that CAP reform was more radical and based on the proposition of the EU commission (European Commission 2003), except that CAP extensification premia were kept at Agenda 2000 level (due to potential environmental benefits). Small additional support for grasslands was assumed but otherwise the national support, environmental support and LFA supports, all rather specific to Finland, were assumed unchanged in the INT scenario. The LIB scenario was a very radical one since it was as- 


\section{Lehtonen et al. Economic and environmental performance of policy measures}

sumed that all agricultural supports, including all the ones mentioned above, were decoupled from production and paid for all farmland in flat-rate basis, after a reduction of $15 \%$, while EU prices of agricultural products were decreased. The same agricultural policy scenarios were used in the paper of Lehtonen et al. (2007) but that article evaluated impacts of agricultural policies on field scale nutrient runoff at two rather small catchment areas by linking DREMFIA with a field scale nutrient runoff model.

The results of Lehtonen et al. (2005) and Lehtonen et al. (2007) suggest that decoupling agricultural supports from production, thus decreasing the incentive to produce, may reduce overall nutrient surplus but there may be individual relatively competitive production regions where production increases and where nutrient leaching might be increasing. Another main result from Lehtonen (2005) was that full scale trade liberalisation, including full decoupling of all forms of agricultural support, reduction in product prices (notably beef and feed grain), and $15 \%$ decrease in the support level, would decrease domestic production very significantly but would not lead to any additional environmental benefits, in terms of nutrient balances, in addition to partial decoupling of agricultural supports due to CAP reform 2003. The main reason for this result was the rapidly increasing feed grain imports which increased nutrient balances in regions relatively competitive in animal production. However, this result was somewhat dependent on the assumption of decreasing EU level product prices and decreasing overall support paid for agriculture. In this paper we test if the decoupling of national subsidies, which are more production linked than the earlier Agenda 2000 CAP-payments, is a relatively efficient means of decreasing nutrient balances relative to more specific agri-environmental policy measures.

However, the EU level macro-scale scenarios of agricultural policies analysed in the earlier DREMFIA applications are not sufficient when evaluating domestic choices in agri-environmental policies in Finland. LFA, national and environmental support play a remarkable role in Finland since CAP payments are only $30 \%$ of the total agricultural support.

This paper is distinct from the earlier DREMFIA applications also in terms of model specification, not only in terms of policy scenario definition. In the previous applications, regional nutrient balances were reported as externalities, calculated based on the model outcomes in different policy scenarios. In this application regional nutrient balances and fertiliser taxes are implemented in the objective function of the DREMFIA model, i.e. we try to internalise the externality of high nutrient balances through the modelled economic instruments. The DREMFIA model allows us to explore the nature of the adjustment paths over time as a response to alternative policies.

We report nutrient balances (and thus nutrient surpluses) since they predict nutrient runoff from farmlands which in turn affects water quality. Economics-driven factors, such as production volume, intensity of production, spatial location, and management practices of agriculture, are considered as primary driving forces for nutrient surpluses on farmlands.

The paper is organised as follows: In the following section some of the previous studies that used economic modelling for analysing the cost-effectiveness of alternative policy measures to reduce nutrient runoff from agriculture are briefly reviewed. Alternative agricultural and agri-environmental policy scenarios are then presented and interpreted. This is followed by presentation of the agricultural sector model employed in this study as well as the nutrient surplus indicators used in the analysis. Results from analysis are then presented and paper concludes with discussion of the results and the chosen approach for this study.

\section{Review of literature}

We start by reviewing briefly some recent studies that have analysed the effectiveness and costeffectiveness of different policy measures to reduce nutrient runoff from agriculture. 
Vol. 16 (2007): 421-440

Mapp et al. (1994) analyse regional water quality impacts of limiting $\mathrm{N}$ use by broad versus targeted policies in five regions within the Central High Plains. Broad based policies analysed include: (i) limitations on the total quantity of $\mathrm{N}$ applied (total restriction) and (ii) limitations on per-acre $\mathrm{N}$ applications (per-acre restriction). Targeted policies analysed include: (iii) limits on the quantity of $\mathrm{N}$ applied on soils prone to leaching (soil targeted restriction) and (iv) specific irrigation systems (system-targeted restriction). Their results show that targeted policies provide greater reduction in environmental damage for each dollar reduction in net farm income, that is, targeted policies are more cost-effective than broad policies. Among the targeted policies $\mathrm{N}$ restrictions differentiated on production systems outperform $\mathrm{N}$ restrictions on soil types.

Vatn et al. (1997) developed an interdisciplinary modelling approach named ECECMOD to analyse the regulation of non-point source pollution from agriculture. They analyse the impacts of following policy scenarios on losses of N, P and soil: (i) $100 \%$ tax on $\mathrm{N}$ in mineral fertilisers, (ii) $50 \%$ arable land requirement on catch crops/grass cover, and (iii) a per hectare payment for spring tillage. The $\mathrm{N}$ tax induces both reduced fertiliser levels, more clover in the leys and better utilisation of $\mathrm{N}$ in manure. However it does not have any effect on soil or P losses. Requirement for catch cropping reduces all categories of losses and losses of nitrates are reduced twice as much as in the tax regime. Subsidising spring tillage has a stronger effect on soil losses than the catch crop regime, but it has insignificant effect on nitrate leaching. Tax on $\mathrm{N}$ is the least costly measure per ha and per $\mathrm{kg}$ reduced $\mathrm{N}$ leached, catch crops are more costly but they have positive effects on erosion and P losses as well. If the focus is exclusively on erosion then spring tillage is the least costly measure.

Johansson and Kaplan (2004) investigate the regional interaction of agri-environmental payments and water quality regulation (a carrot-andstick approach) in animal and crop production setting by using the U.S. Regional Agricultural Sector Model (USMP), which maximises profits from livestock, poultry and crop production in the presence of agri-environmental payments and nutrient standards. Crop and animal production choices are linked to edge-of-field environmental variables using the Environmental Policy Integrated Climate Model (EPIC). The results show that meeting nutrient standards would result in decreased levels of animal production, increased prices for livestock and poultry products, increased levels of crop production, and water quality improvements. The impacts of nutrient policies are not homogeneous across regions; in regions with relatively less cropland per ton of manure produced these impacts are more pronounced. However, requiring the spread of manure at no greater than agronomic rates may not quarantee positive effects on each and every region. Increased product prices due to decreased production in intensive production areas could lead to increased leaching of $\mathrm{N}$ in other areas, if no additional agri-environmental payments were introduced to encourage adoption of environmentally benign production practices.

Abrahams and Shortle (2004) developed an empirical simulation model of corn production in the United States and its impacts on nitrate pollution, and examined taxes and standards on purchased nitrogen fertilizer and taxes and standards on excess $\mathrm{N}$ (that is, $\mathrm{N}$ surplus). These environmental policy instruments are examined with and without corn price support and land retirement policies. The results show that economically efficient nitrate policy choices are sensitive to agricultural income support programs: in the presence of income support programs, the preferred instrument is a fertiliser tax, whereas without the support programs, the preferred instrument is an excess $\mathrm{N}$ tax. Huang and LeBlanc (1994) have analysed the cost-effectiveness of excess $\mathrm{N}$ tax in comparison to $\mathrm{N}$ fertilizer tax. Their results indicate that excess $\mathrm{N}$ tax may be more cost-effective than fertilizer tax.

Cost-effectiveness of alternative agrienvironmental policy instruments in reducing $\mathrm{N}$ or $\mathrm{P}$ runoff on the basis of Finnish data have been analysed e.g. by Lankoski and Ollikainen 1999, Iho 2005 and Helin et al. 2006. However, the emphasis in these studies 
is in theoretical set-up and crop production and their results are not directly comparable to this study.

\section{Alternative policy scenarios to reduce nutrient loading from agriculture}

Current agri-environmental policy in Finland is based on three tier system: mandatory basic measures, additional measures and special measures. The farmer who participates in the program has to implement five mandatory basic measures, such as crop specific nutrient use restrictions and buffer strips, and at least one additional measure, such as reduced tillage. Special measures are environmentally more effective measures and they include such measures as large buffer zones and constructed wetlands. The agri-environmental support is relatively more important for farm income in Finnish plant production farms than livestock farms. Agri-environmental support, when compared to farm income in gross terms, comprises $52 \%$ of farm income in plant production farms, $10-17 \%$ in pig farms and $13-22 \%$ in dairy farms (Koikkalainen and Lankoski 2005). However the agri-environmental support imposes also costs for a farm through fertilisation restrictions and due to the fact that crop production in required, i.e. agri-environmental support is not paid for set-aside. Hence the support is directly coupled to plant production but much less coupled to animal production. In fact, the agri-environmental support paid for crops should extensify animal production, in addition to setting a limit for fertilisation level.

Basic and additional measures support in the current Agri-Environmental Program has had an important role as green payments that have promoted both environmental and farm income objectives, but have not been particularly effective in nutrient runoff reduction (Granlund et al.
2005, Ekholm et al. 2007). The monitored nutrient leaching from farmland has not decreased despite the fact that chemical nitrogen fertiliser sales have decreased by appr. $25 \%$ and phosphorous fertiliser sales by $57 \%$ in $1995-2005$. On the other hand, the manure nutrients have not decreased but increased in intensive areas of animal production, since pork and poultry meat production have increased by $20 \%$ and $100 \%$, respectively, in 1995-2005. Beef production has decreased by $12 \%$ while there has been little change in milk production in 1995-2005 (Niemi $\&$ Ahlstedt 2006). There is a need to find new alternative policy measures in order to meet the water quality protection targets of Finnish agriculture. We analyse the following policy scenarios.

\section{The baseline scenario}

The on-going Common Agricultural Policy (CAP) reform scenario (from now on the BASE scenario) follows the CAP reform agreement made in June 2003, according to which most direct CAP subsidies will be decoupled from production and paid in a single, lump-sum farm payment based on 2000-2002 historical production levels. The Finnish government started the implementation of the reform in 2006. From there on, all CAP arable area payments became decoupled from production and a regionalised flat-rate payment is paid for all farms and all crops (including set-aside, but excluding some permanent crops). However, $69 \%$ of bull premia and $100 \%$ of suckler cow premia will remain coupled to production, i.e. paid per animal. The sum of coupled bull and suckler cow premia will not exceed $75 \%$ of the bull premia paid in the reference period 2000-2002. Decoupled CAP animal support, based on 2000-2002 production levels, will be paid for individual cattle and milk farms. However after 2010 these farm specific top-ups are gradually shifted to regional flat rate payments until 2016. Overall, circa $90 \%$ of CAP support will be decoupled. Furthermore, $5 \%$ of all direct EU payments will be cut (modulated) from 
2007. CAP payments amounted to $€ 541$ million (30\% of all farm support) in 2006.

Receiving the decoupled CAP support will not require any agricultural commodity production. However, farmland has to be kept in good agricultural and environmental condition and this means that land has to be either cultivated or kept as set-aside land. In Finland, there is a national decision about the cross compliance condition for CAP single farm payment: uncultivated CAP area, which is not obligatory CAP set-aside area, has to be established as grassland, i.e. there has to be vegetation cover typical for grasslands representing good local cultivation practice. This means in practice that grasslands have to be re-sown as grasslands every 5 years because of wintertime damages on grass vegetation. In other words, there are certain costs related to CAP payment entitlements.

Another national option in CAP reform was to re-direct some part, $10 \%$ of the sector specific CAP payments at maximum, to winter cereals and oilseeds in Finland in 2006. If the total sum of this special support exceeds a ceiling of $€ 5.8$ million, the payment per hectare (estimated as $€ 47 / \mathrm{ha}$ ) is reduced correspondingly. This is automatically taken into account in the DREMFIA model.

In the BASE scenario, no change in the EU level cereal prices is assumed. The intervention price for butter is reduced by $25 \%(-7 \%$ in $2004,2005,2006$, and $-4 \%$ in 2007). For skimmed milk powder (SMP), prices will be cut by $15 \%$. In 2007 , it is assumed that the overall decrease in the average producer price of milk at the EU level will be $12 \%$ down from the 2003 price level. The price cuts will be compensated by a direct payment of $€ 35.50$ per ton of milk quota. This payment became fully decoupled in 1st April 2006.

The 2006 agri-environmental support scheme is assumed unchanged up to 2020. This assumption is counter-factual but necessary for reference purposes when evaluating the subsequent scenarios. The environmental support is paid as a flat rate payment per hectare of cultivated farmland, but not on set-aside land, except in rare cases. Agri-environmental support paid for livestock farm is slightly higher than that paid for crop farm, generally the support level varies between $€ 93$ and $€ 120$ per hectare. The purpose of the payment is to promote a number of environmentally friendly management practices and compensate for the incurred costs. The general condition of the payment is that farmer is obliged to limit fertiliser use and the time of manure application. The total sum of environmental support payments was $€ 284$ million in 2005 (16\% of all farm support and $35 \%$ of aggregate farm income).

Other elements assumed to stay unchanged in the BASE scenario are Less Favoured Area (LFA) payments ( $€ 418$ billion in 2005) and national supports (€572 million in 2005). LFA support is paid as a flat rate area payment for all crops while a large part of national support is paid per animal, per litre of milk and per hectare of specific crops. In the LFA support scheme, there is a condition that if a farmer allocates more than $50 \%$ of his or her land to set-aside, then LFA support will be cut. For example, if $60 \%(70 \%)$ of farmland is set-aside, LFA payments are cut by $20 \%(40 \%)$. If a farm allocates all land to set-aside, no LFA support is paid.

\section{Full decoupling of national support}

In this scenario (abbreviated as NDEC1) all agricultural supports and prices are kept the same as in the BASE scenario, but national supports paid per hectare and animal, or litre of milk, are decoupled from production and paid as a per hectare payment, no matter of production, as long as the land is kept in good agricultural condition by set-aside, for example. National price support for milk was $€ 188$ million (Table 1), other animal linked support was $€ 164$ million, and hectare based support was $€ 220$ million in 2005. In total, national support amounted to $€ 572$ million in 2005. Compared to the BASE scenario where no national support is paid for set-aside, decoupling all this support from production in this scenario provides an incentive to increase set-aside area. 


\section{Lehtonen et al. Economic and environmental performance of policy measures}

Table 1. National producer price support for milk (c/litre), and payments (€/animal unit) per animal unit of some animals in different support zones in Finland in 2006. Suckler cow $=1$ unit, bull $=0.6$ units, sow $=0.7$ units, fattening pig $=0.23$ unit, laying hen $=0.013$ units, broiler $=0.0053$ units.

\begin{tabular}{llccccc}
\hline Zones & & Milk & Suckler Cows & Bulls & Pigs and sows & Poultry \\
\hline A and B & (southern Finland) & 3.3 & 80 & 208 & 206 & 191 \\
C1 & (central Finland) & 7.6 & 296 & 417 & 293 & 262 \\
C2 & (central Finland) & 8.2 & 296 & 425 & 253 & 231 \\
C2north. & (central Finland) & 9.5 & 372 & 501 & 296 & 283 \\
C3: P1 & (northern Finland) & 12.5 & 447 & 577 & 296 & 283 \\
C4: P4 & (northern Finland) & 21.5 & 632 & 762 & 296 & 283 \\
\hline
\end{tabular}

\section{Partial decoupling of national supports from production}

In this scenario (abbreviated as NDEC2) all other supports and prices are kept the same as in the BASE scenario, but national supports paid for heads of animals in AB -support regions (Southern Finland) are decoupled from production. Since national supports are higher elsewhere in the country (C-support regions located in central and northern Finland) this partial decoupling decreases the production linked national supports paid in support region $\mathrm{C}$ by the amount of national support paid in southern Finland. In the case of plant production $50 \%$ of the national support is decoupled and $50 \%$ is production linked throughout the country. National supports for crops are approximately the same in the whole country.

\section{Payments on decreased nutrient surplus}

In this scenario (abbreviated as BAL) it is assumed that from 2008 a farmer is paid a full amount of agri-environmental support ( $€ 100 /$ ha) only if he/ she decreases both $\mathrm{N}$ and $\mathrm{P}$ surpluses by $50 \%$ from the 1995 level. In other words, decreasing the $\mathrm{N}$ surplus by $50 \%$ brings $€ 50$ per hectare of all farmland regardless of production, and decreasing the P surplus by $50 \%$ brings another $€ 50$ per hectare of land regardless of production. Thus, every $1 \%$ drop in the nutrient balance of $\mathrm{N}$ or P yields $1 €$ per ha for the farmer. Allocating all land to setaside would then mean $100 \%$ reduction in nutrient balance and yield $200 € /$ ha for the farmer. On the other hand, a major income drop may take place if nutrient surpluses are not reduced significantly in the period 1995-2008. For example, if the reduction is only $30 \%$ (i.e. $60 \%$ of the target of $50 \%$ reduction) in both $\mathrm{N}$ and $\mathrm{P}$ surplus, the farmer receives agri-environmental support of $€ 60$ per hectare. All other supports and prices are kept the same as in the BASE scenario.

\section{Tax on $\mathrm{N}$ fertiliser}

In this scenario (abbreviated as FTAX) we assume a tax of $21 \mathrm{c} / \mathrm{kg}$ of $\mathrm{N}$ fertiliser, from year 2008 . This means that the tax rate varies in different compound fertilisers, e.g. from $7 \%$ up to $40 \%$, depending on the $\mathrm{N}$ content. The average tax rate is approximately $20 \%$. The tax is not compensated to farmers.

\section{The model and calculation of nutrient balances}

\section{The sector model}

DREMFIA is a dynamic recursive model which simulates rational economic behaviour and the effects of various agricultural policies on land use, animal production, farm investment and farmers' income. The model consists of two major parts: 


\section{AGRICULTURAL AND FOOD SCIENCE}

Vol. 16 (2007): 421-440

(1) a technology diffusion model which determines sector level investments in different production technologies, and

(2) an optimisation routine which simulates annual production decisions (within the limits of fixed factors) and price changes, i.e., supply and demand reactions, by maximising producer and consumer surpluses subject to regional product balance and resource (land and capital) constraints (cf. Fig. 1).

The optimisation model is a typical spatial price equilibrium model (see e.g. Cox and Chavas 2001), except that no explicit supply functions are specified (i.e. supply is a primal specification). Furthermore, foreign trade activities specific to 4 main regions are included in DREMFIA. The Armington assumption (Armington 1969), which is a common feature in international agricultural trade models but less common in one-country sector models, is used. Imported and domestic products are imperfect substitutes, i.e., endogenous prices of domestic and imported products are dependent. There are 18 different processed milk products and their regional processing activities in the model. Milk fat, protein and casein are used in production in 18 different dairy products.
Four main areas are included in the model: southern Finland, central Finland, Ostrobothnia (the western part of Finland), and northern Finland. Production in these is further divided into sub-regions on the basis of the support areas. In total, there are 18 different production regions. This allows a regionally disaggregated description of policy measures and production technology. The final and intermediate products move between the main areas at certain transportation cost. The most important products of agriculture are included in the DREMFIA model. Hence, the model provides a complete coverage of land use and animal production, which compete on production resources. A more detailed description of model can be found in Lehtonen (2001).

Technical change and investments, which imply evolution of farm size distribution, are modelled as a process of technology diffusion. Investments are dependent on economic conditions such as interest rates, prices, support, production quotas, and other measures imposed on farmers.

The use of variable inputs, such as fertilisers and feed stuffs, is dependent on agricultural product prices and fertiliser prices through production functions. The nutrients from animal manure are explicitly taken into account in the economic

\begin{tabular}{|c|c|}
\hline Optimisation & $\begin{array}{l}\text { Policy scenarios } \\
\text { supports for farmers } \quad \text { EU prices }\end{array}$ \\
\hline \multirow{3}{*}{$\begin{array}{l}\text { MAX: producer and consumer surplus } \\
-\quad \text { annual market equilibrium } \\
-\quad \text { different yields and inputs in regions } \\
-\quad \text { feed use of animals changes } \\
\text { endogenously } \\
\text { - constraints on energy, protein and } \\
\text { roughage needs of animals } \\
-\quad \text { nonlinear yield functions for dairy cows } \\
-\quad \text { domestic and imported products are } \\
\text { imperfect substitutes } \\
-\quad \text { processing activities of milk and sugar } \\
\text { - export cost functions }\end{array}$} & $\begin{array}{c}\text { Crop yield functions } \\
\text { - } \quad \text { optimal level of fertilisation }\end{array}$ \\
\hline & \begin{tabular}{ll} 
& \multicolumn{1}{c}{ Steering module } \\
- & bounds for land use variables; \\
- & validated to observed data \\
$-\quad$ & inflation \\
$-\quad$ & increase in crop and animal yield \\
& potential
\end{tabular} \\
\hline & $\begin{array}{l}\text { Model of technology diffusion } \\
-\quad \text { endogenous sector level }\end{array}$ \\
\hline $\begin{array}{l}\text { Results/Initial values } \\
\text { production land use consumption prices } \\
\text { imports exports transportation }\end{array}$ & $\begin{array}{l}\text { profitability and accessibility of } \\
\text { each technique } \\
\text { gradual shifts of capital to best } \\
\text { performing techniques }\end{array}$ \\
\hline
\end{tabular}

Fig. 1. Basic structure of the DREMFIA model. 


\section{Lehtonen et al. Economic and environmental performance of policy measures}

model. Feeding of animals may change provided that nutrition requirements, such as energy, protein, $\mathrm{P}$ and roughage needs, are fulfilled. In the feasible range of inputs per animal, production functions model the dependency between the average milk yield of dairy cows and the amount of concentrates and other grain based feed stuffs. Since in historical farm level data there are relatively few observations of high levels of concentrates, the dataset is enriched by experimental data. A number of research trials have been made by agro-biological research on the yield response effects of significant changes in animal feeding and plant fertilisation (Sairanen et al. 1999, 2003; Bäckman et al. 1997). However the new farm level data of animal feeding is richer (there is more variation) than the earlier one since farmers gradually increase the use of feed concentrates (Pro Agria 2005).

The yield level of the different crops is determined separately for each year and for the 18 production regions. The yield levels are obtained by determining the optimum fertilisation at the farm level using equation (1).

$$
\frac{d F(N)}{d N}=\frac{P_{f}}{P_{c}}
$$

$\mathrm{F}(\mathrm{N})$ is the fertilisation response function in terms of $\mathrm{N}, \mathrm{P}_{\mathrm{f}}$ is the price of $\mathrm{N}$, and $\mathrm{P}_{\mathrm{c}}$ the price of the crop product. Crop prices $P_{c}$ may be expected prices, intervention prices or market prices of the previous year.

As the fertilisation response function, the Mitscherlich function

$F_{m}(N)=m\left(1-k e^{-b N}\right)$

where $\mathrm{F}$ is yield per hectare, $\mathrm{N}$ is nitrogen use per hectare and $\mathrm{m}, \mathrm{k}$ and $\mathrm{b}$ are the parameters, is used for barley, malting barley, wheat, oats, mixed cereals and peas. The quadratic function

$F_{q}(N)=a+b N+c N^{2}$

is used for rye, potatoes, sugar beet, hay, silage, green fodder and oilseeds.
The Mitscherlich function was preferred to quadratic function since the quadratic function results to rather small changes in the $\mathrm{N}$ fertilisation and crop yield levels even in the case of large changes in the relation between the fertiliser price and crop price. This was also noted by Ylätalo (ed.) (1996, p. 64-65). According to Ylätalo (ed), the change in relative prices of fertilisers and crops due to the EU membership, which brought crop prices down by $40-60 \%$ and fertiliser prices down by $10-20 \%$, would result in a $11 \%$ decrease in fertilisation of wheat when a quadratic response function were used, while the Mitscherlich function would result in a $22 \%$ decrease in the fertilisation of wheat. These changes in fertilisation, in turn, would lead to a $2.5 \%$ decrease of crop yield in the case of the quadratic function, and to a $4.8 \%$ decrease of crop yield in the case of Mitscherlich function.

Hence the changes in crop yield level due to minor and temporary price shocks are almost negligible, according to the crop response functions used in this study. However, together with the concavity of the crop response functions, the increasing energy and fertiliser prices and decreasing prices of crops, as observed in period 2000-2005, are likely to result in relatively larger reductions in the crop yield levels. For example, introducing a $20 \% \mathrm{~N}$ fertiliser tax in the FTAXscenario decreases $\mathrm{N}$ fertilisation level by $5-15 \%$, and the crop yield levels by $2-4 \%$. Hence it seems that the reduction in crop yields due to $20 \% \mathrm{~N}$ tax would be almost comparable to the effect of the EU integration. On the other hand, relative reduction in the crop yield level is still smaller than the reduction in fertiliser use. This means that $\mathrm{N}$ surplus could slightly decrease for every crop ceteris paribus.

Milk quotas, which constrain milk production at farm and country level, are traded within three separate areas in the model. Within each quota trade area, the sum of quotas purchased must equal the sum of quotas sold. The price of the quota is the weighted sum of the shadow values of an explicit quota trade balance constraint in each quota trade area. Milk quota trade results in increasing production efficiency. The observed 
milk quota prices have served a valuable reference in the model validation.

The overall model replicates very closely the ex post production development in 1995-2005. Official agricultural production and price statistics (TIKE 2007) has been used as the basis in validation. Calibrating the unobserved parameters of the investment model (discussed above) is a significant part of the overall validation of the model. Price changes in 1995-2005 have been validated through calibrating the unobserved parameters in the Armington system and in export cost specification (see Lehtonen 2001, 2004 for details). The total value of each single input, calculated from input specifications of many production activities in the model, has been checked and validated using cross sectional statistical data (Statistics Finland 1995, 2004). Furthermore, the total quantities of inputs, not only the total values of inputs and outputs, are also validated to observed aggregate levels. Hence, the validation of the model is consistent as well in terms of the physical flows of inputs, such as fertilisers and feed stuffs, particularly relevant in analysing environmental effects and economic adjustments to changes in agricultural policy.

The model is built to reach the steady-state equilibrium, in terms of production volume and regional location of production, in a 10-15 year period given no further policy changes. While certain features in the model facilitate adjustments of both fixed and variable factors of production, fixed production factors and animal biology make immediate adjustments costly. For example, production functions in the model are concave, i.e. the marginal productivity is decreasing with output. Increasing exports are expensive because of low European Union price level compared to production and transportation costs. Armington assumption and the assumption that consumers prefer domestic products also contribute to the steady states, i.e. the scarcity of domestic food stuffs slightly increase producer prices $(1 \%-15 \%$ on the producer price level) when validated to observed price development.

\section{Nutrient balances}

The soil surface $\mathrm{N}$ and $\mathrm{P}$ balances for each crop are calculated as the difference between the total quantity of $\mathrm{N}$ or $\mathrm{P}$ inputs entering the soil and the quantity of $\mathrm{N}$ or $\mathrm{P}$ outputs leaving the soil annually.

The soil surface balances (surplus/deficit) for $\mathrm{N}$ and $\mathrm{P}$ per total agricultural land in each region in the model were calculated by adding the total nutrient content of fertilisers (summed over all crops), organic manure of all animals, and $\mathrm{N}$ depositions, and by subtracting the nutrient content of the harvest (summed over all crops) and losses to the atmosphere $(5 \mathrm{~kg} \mathrm{~N} / \mathrm{ha})$. The calculated net nutrient surplus $(\mathrm{kg} / \mathrm{ha})$ provides an indicator of the production intensity, and of the potential nutrient losses and environmental damage to surface and ground waters.

For the sake of completeness two sets of nutrient balances were calculated:

1) for all available farmland no matter of use in order to monitor the aggregate change in the intensity of all farmland use;

2) for all farmland used in production (excluding set-aside and idled land) in order to monitor aggregate changes in active production area;

These two balances are necessary to avoid biased conclusions. For example, nutrient surpluses calculated for all farmland may decrease while nutrient surpluses for active production area may increase. In that case, the total nutrient runoff may even increase.

\section{Results}

\section{Effects on production and land use}

Milk production comprises close to $50 \%$ of added value in Finnish agriculture (Niemi and Ahlstedt 2006). With the CAP reform, the linkage between milk payments and milk quotas is removed. Decoupled CAP payments and cuts in milk price re- 


\section{Lehtonen et al. Economic and environmental performance of policy measures}

duce incentives to invest in milk production in all scenarios. According to the model results, production decreases temporarily $5 \%-10 \%$ in the period 2009-2012 but recovers soon to the level of 2005 (Table 2). The endogenous milk quota prices in the DREMFIA model decrease from the average level of 10-30 c/litre (varying between $20-40 \mathrm{c} /$ litre in northern and central Finland and 10-20 c/litre in southern Finland 2000-2005) down to zero in most parts of the country until 2008 when milk quotas are not binding in any of the three quota trade areas. This means that the decrease in the incentive to produce milk in the CAP reform scenario is greater than the value of milk quota. Hence unlike in many other EU countries the CAP reform effect is not absorbed in (decreased) quota prices (see, for example, Lips \& Rieder 2005) in Finland but results in a temporary reduction in production volume. However, in central and eastern Finland and Ostrobothnia region the milk quota prices start to recover already at 2010 and reach pre-reform levels by 2013 . The recovery in dairy investments and milk quota prices is facilitated by rapid structural change in 1995-2005 as well as national payments per litre of milk which dampen the CAP reform effect. However, in the other trade areas in southern and northern Finland the quota prices do not reach pre-reform levels until 2020. Without the quota trade area boundaries these regions would loose their quotas and production to eastern Finland and Ostrobothnia. According to the results milk production may reduce substantially and quotas will not be filled in northern Finland where dairy is the dominant line of production. Relatively most competitive milk production regions, such as Ostrobothnia where the share of large and enlarging dairy farms is the highest, benefit from the decreasing values of milk quotas. Hence, some milk quotas from central Finland shift to Ostrobothnia. The temporary reduction in overall production volume provides opportunities for expanding dairy farms. This leads to increasing regional concentration of milk production.

Alternative policy scenarios BAL and FTAX, on top of the BASE scenario, have a minimal impact on aggregate milk production volume in
Finland (Table 2). However, the BAL scenario results in slightly higher milk production since milk production is already more extensive in terms of land use than pork and poultry production which are regionally concentrated in South-West Finland. Hence, it is relatively cheaper to extend milk production than pork production. Pork production decreases appr. 20\% below the BASE scenario level in the BAL and FTAX scenarios until 2020. Beef production decreases $12 \%$ below the BASE scenario level in the BAL scenario. Farms specialised in beef production aiming to reach economies of scale, and which have grown at a rapid rate in recent years, face considerable economic costs due to increasing nutrient balances. Consequently, the number of suckler cows ( $10 \%$ of the total cows in 2005) does not increase at all in the BAL scenario whereas the number of suckler cows increases by $80 \%$ in the BASE scenario in the period 2005-2020. The increase of suckler cows in the BASE scenario is explained by the national payments per head (in northern areas they are higher per head than CAP premiums), as well as the $100 \%$ coupling of CAP-suckler cow premia and $69 \%$ coupling of CAP-bull premia (within the budgetary limits, i.e. increasing number of animal implies lower per unit CAP-payments). Furthermore, in the case of unprofitable milk production dairy farms may shift to suckler cow production without much additional investment. Higher payments to grasslands (regional flat rate payments) due to CAP reform provide also relatively higher stimulus for suckler cow production than for more intensive milk production.

The decoupling of CAP payments, the milk price reduction combined with decoupled compensatory milk payments, and decoupling national price supports for milk, have a major impact on land use (Figs. 2-4). Since many farms are small and production costs are high, most dairy farmers who exit milk production make the minimum effort to receive CAP and national payments, i.e., they leave their land as set-aside (Fig. 2) instead of cultivating cereals on former grasslands which has been the trend in 1995-2005. Cereal area has increased by $20 \%$ and grassland decreased by $12 \%$ in 1995-2002. 
Vol. 16 (2007): 421-440

Table 2. Milk (million litres) and meat production (million kg) in different policy scenarios in 2020. BASE $=$ No changes in agricultural policy after 2007; NDEC1 = Full decoupling of national support; NDEC2 = Partial decoupling of national supports; BAL = payments for reduced nutrient surpluses; FTAX $=$ Tax on nitrogen fertiliser.

\begin{tabular}{lccccc}
\hline & BASE & NDEC1 & NDEC2 & BAL & FTAX \\
\hline $\begin{array}{l}\text { Milk } \\
\text { 2005: 2293 mill. litres }\end{array}$ & 2316 & 1518 & 1986 & 2360 & 2257 \\
$\begin{array}{l}\text { Beef } \\
\text { 2005: } 84 \text { mill. kg }\end{array}$ & 77 & 59 & 71 & 68 & 76 \\
$\begin{array}{l}\text { Pork } \\
\text { 2005: 203 mill. kg }\end{array}$ & 179 & 160 & 160 & 158 & 165 \\
$\begin{array}{l}\text { Poultry } \\
\text { 2005: } 87 \text { mill. } \mathrm{kg}\end{array}$ & 86 & 85 & 85 & 85 & 86 \\
\hline
\end{tabular}
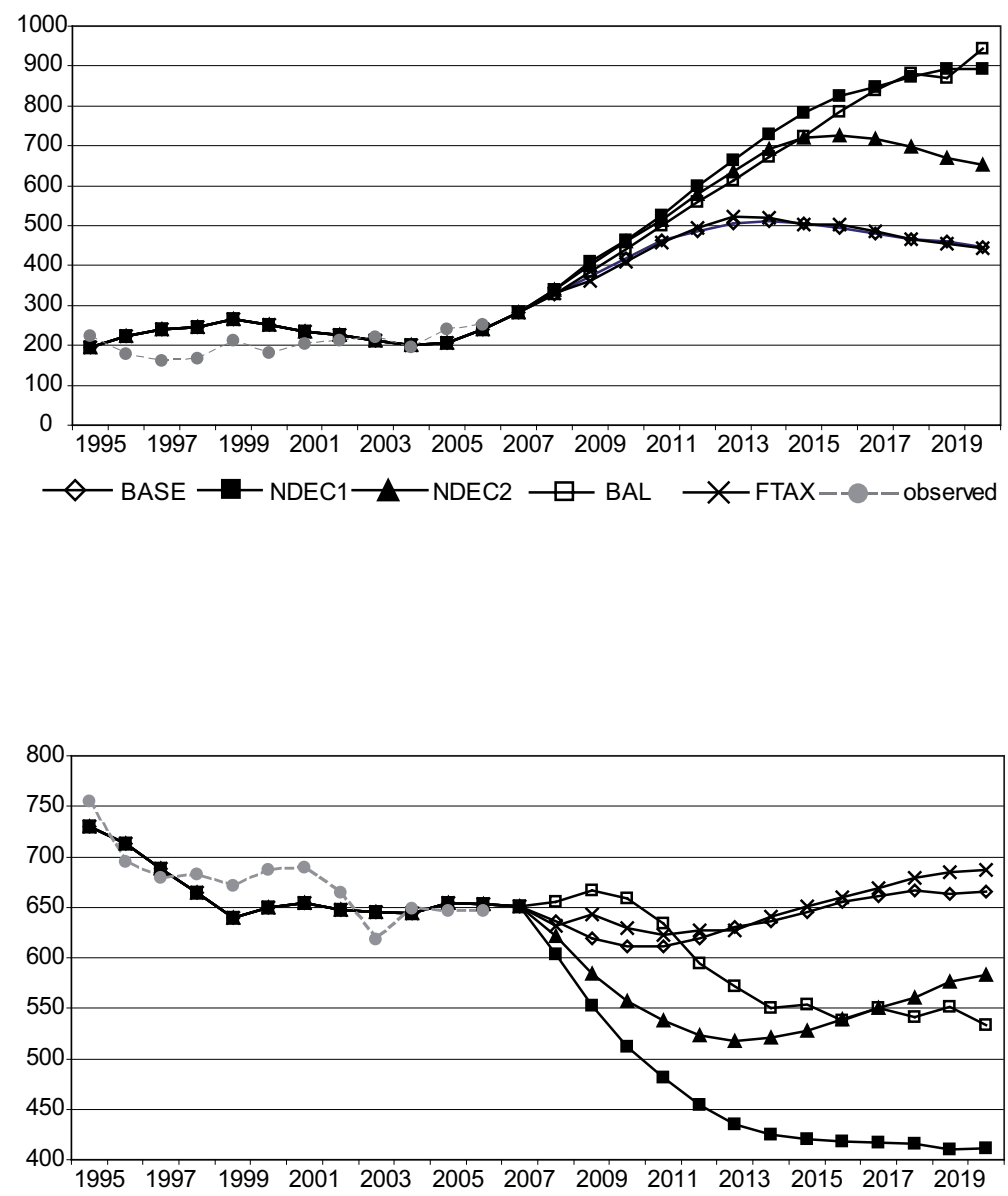

$\diamond$ BASE $\rightarrow$ NDEC1 - NDEC2 $\square$ BAL $\rightarrow$ FTAX--0-observed
Fig. 2. Area $(1,000$ ha) under set-aside. BASE = No changes in agricultural policy after 2007; NDEC1 = Full decoupling of national support; NDEC2 $=$ Partial decoupling of national support; $\mathrm{BAL}=$ payments for reduced nutrient surpluses; FTAX = Tax on nitrogen fertiliser.

Fig. 3. Area (1,000 ha) under grass cultivation. BASE $=$ No changes in agricultural policy after 2007; NDEC1 = Full decoupling of national support; NDEC2 = Partial decoupling of national support; BAL = payments for reduced nutrient surpluses; FTAX = Tax on nitrogen fertiliser. 
Lehtonen et al. Economic and environmental performance of policy measures

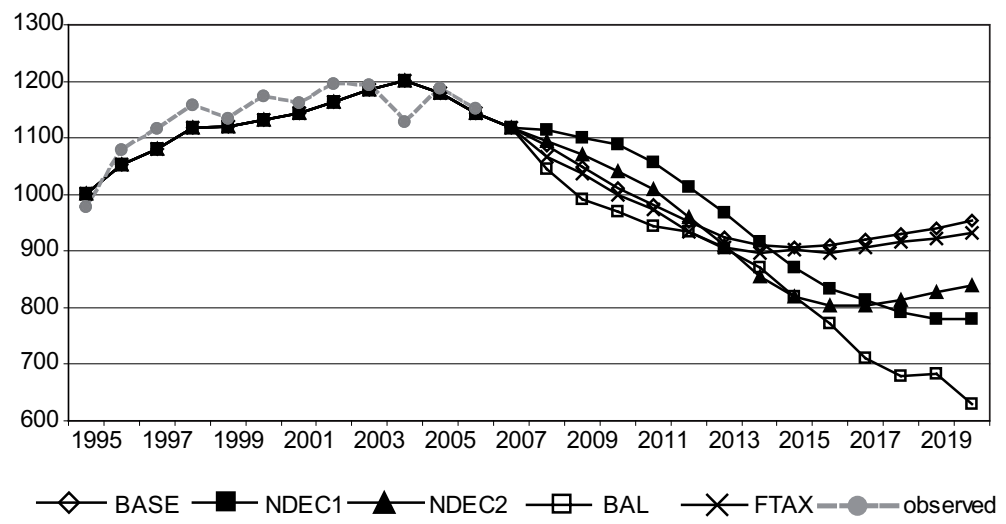

Fig. 4. Area (1,000 ha) under cereal cultivation in Finland. BASE $=$ No changes in agricultural policy after 2007; NDEC1 $=$ Full decoupling of national support; NDEC2 = Partial decoupling of national support; $\mathrm{BAL}=$ payments for reduced nutrient surpluses; FTAX = Tax on nitrogen fertiliser.

\section{Environmental and economic performance of the policy scenarios}

In this section we use following three criteria to evaluate the performance of alternative policy scenarios: (i) environmental effectiveness is shown directly by the change in $\mathrm{N}$ or $\mathrm{P}$ balance under given policy scenario in comparison to base scenario, (ii) abatement costs for farmers (farm level cost effectiveness) in reducing nutri- ent surplus in each scenario are given by income loss per \% reduction in $\mathrm{N}$ balance or $\mathrm{P}$ balance, and (iii) budgetary cost effectiveness is shown by agri-environmental expenditure per $\%$ reduction in $\mathrm{N}$ balance or $\mathrm{P}$ balance (see Table 4 for these results). The results suggest that the overall area of green fallow (set-aside) will increase considerably on its own due to recent EU CAP reform without additional measures when $90 \%$ of CAP payments are decoupled from the number of animals and hectares of cereals. However, the in-

Table 3. Nitrogen $(\mathrm{N})$ and phosphorus $(\mathrm{P})$ balances $(\mathrm{kg} / \mathrm{ha})$ calculated for all farmland and for cultivated land (excluding set-aside) in different policy scenarios in 2010 and 2020. BASE $=$ No changes in agricultural policy after 2007; NDEC1 = Full decoupling of national support; NDEC2 = Partial decoupling of national support; BAL = payments for reduced nutrient surpluses; FTAX = Tax on nitrogen fertiliser.

\begin{tabular}{lcccrrc}
\hline & Year & BASE & NDEC1 & NDEC2 & BAL & FTAX \\
\hline N balance for all & 2010 & 33.7 & 32.0 & 32.1 & 29.5 & 25.5 \\
farmland & 2020 & 35.2 & 27.2 & 32.0 & 21.6 & 26.2 \\
2005: 39.0 kg/ha & 2010 & 3.5 & 3.0 & 3.2 & 3.1 & 2.7 \\
P balance for all & 2020 & 3.6 & 2.5 & 3.1 & 2.7 & 2.8 \\
farmland & 2010 & 47.0 & 45.4 & 45.6 & 42.1 & 36.6 \\
2005: 4.3 kg/ha & 2020 & 49.1 & 50.8 & 50.5 & 43.1 & 38.2 \\
N balance for & 2010 & 6.0 & 5.2 & 5.5 & 5.5 & 4.9 \\
cultivated farmland & 2005: 48.0 kg/ha & 6.0 & 5.7 & 6.0 & 6.8 & 5.0 \\
$\begin{array}{l}\text { P balance for } \\
\text { cultivated farmland }\end{array}$ & 2020 & & & & & \\
2005: 6.3 kg/ha & & &
\end{tabular}


crease in set-aside area may lead to more intensive production on remaining agricultural land (Table 3 ), and despite the reduction of milk prices by $10-12 \%$ the CAP reform is not likely to decrease overall nutrient surpluses by more than $10-15 \%$, on the average. Further decoupling of agricultural support, namely the production coupled national supports (NDEC1 and NDEC2), would clearly decrease the nutrient surpluses compared to the baseline, but the production volumes of dairy, beef and pork would decrease considerably. Farm income, however, would increase (Fig. 5), so that decrease in nutrient surpluses could be attained at negative abatement costs for farmers. Keeping national supports production linked but paying agri-environmental support only if nutrient surpluses are clearly reduced (BAL), is a policy alternative that would be the most effective in decreasing overall $\mathrm{N}$ surplus, but relatively less effective in reducing $\mathrm{P}$ surplus than full decoupling of national supports. On the other hand, this alternative would not decrease dairy production, but would decrease farm income and cereals and pork production considerably. Simple fertiliser tax (FTAX), on the top of the existing unchanged agricultural supports, appears to have smaller negative impact on farm income and production but is less effective in terms of reducing $\mathrm{N}$ and $P$ surpluses.
Despite the fact that $\mathrm{N}$ surplus for cultivated land decreases steadily and considerably in the BAL scenario, $\mathrm{P}$ surplus on cultivated land, after some decline in 2008-2010, increases again after 2010. This is an indication of the fact that decreasing the $\mathrm{P}$ surplus is relatively more costly than decreasing the $\mathrm{N}$ surplus when the size of livestock farms increase and production concentrates gradually in most competitive regions. For this reason the animal production decreases and concentrates on most competitive regions while set-aside area increases most in less competitive areas in BAL-scenario. The sector level results suggest that BAL leads to strong animal production concentration and even increasing P surpluses in competitive areas whereas large areas of set-aside on less competitive regions will still keep the overall $\mathrm{P}$ balance on the decrease. In other words, in BAL-scenario farmers gradually leave animal production for relatively most competitive producers and utilise the payments for decreased nutrient surpluses. For this reason farm income in BAL-scenario, after a severe drop in 2008 (Fig. 5), reaches the level of farm income of FTAX-scenario until 2019. Increased set-aside and reduced nutrient surpluses in BAL increases agri-environmental payments to the BASE-scenario level until 2020 (Fig. 6).

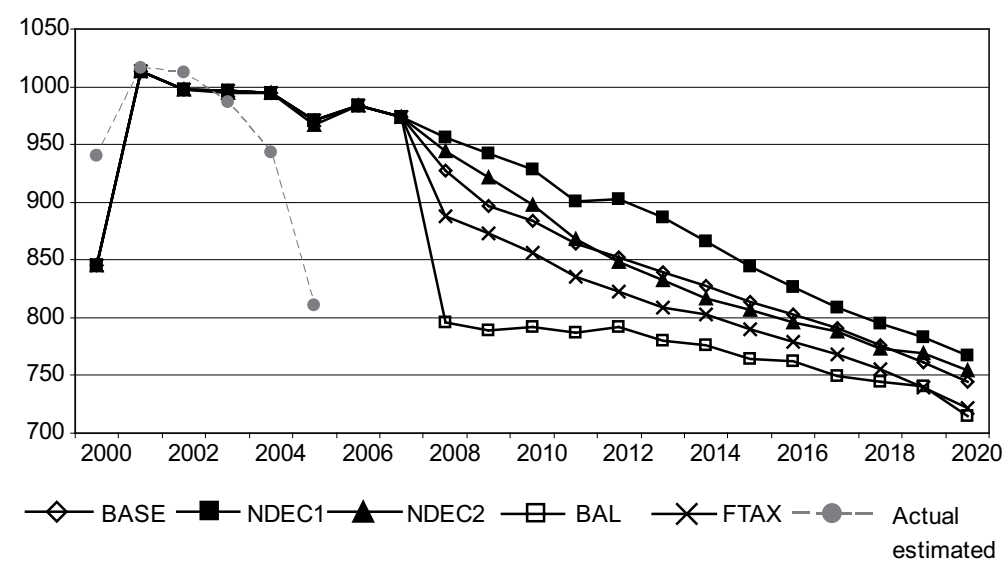

Fig. 5. Agricultural income $(€$ million) in 2005 money. Discount rate $=1.8 \%$ in 2006-2008. Estimate of (cash flow based) agricultural income in Niemi and Ahlstedt (2005) is rather low because of lags in support payments is 2005. BASE $=$ No changes in agricultural policy after 2007; NDEC1 = Full decoupling of national support; NDEC2 = Partial decoupling of national support; $\mathrm{BAL}=$ payments for reduced nutrient surpluses; FTAX = Tax on nitrogen fertiliser. 
Lehtonen et al. Economic and environmental performance of policy measures

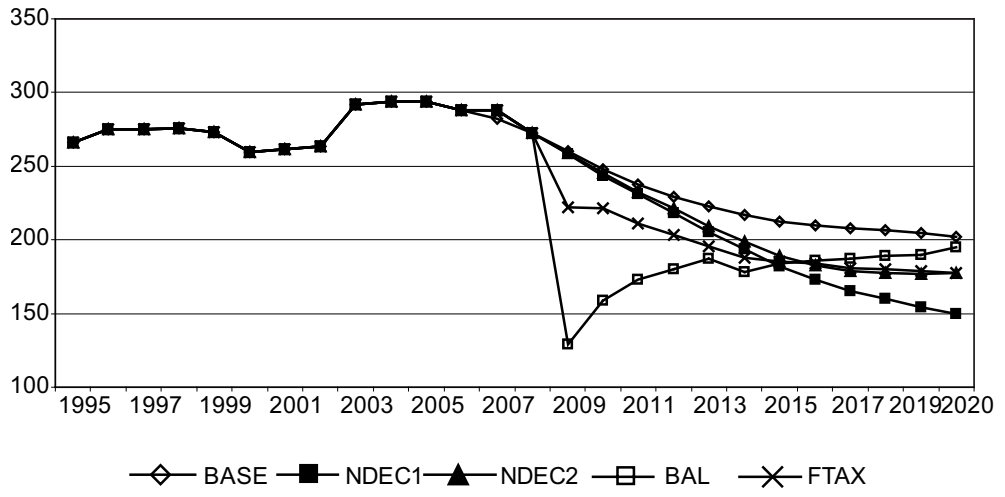

Fig. 6. Expenditure on agri-environmental support $(€$ million) in 2005 money. Discount rate $=1.8 \%$ in $2006-2008$. BASE $=$ No changes in agricultural policy after 2007; NDEC $1=$ Full decoupling of national support; NDEC2 $=$ Partial decoupling of national support; $\mathrm{BAL}=$ payments for reduced nutrient surpluses; FTAX $=$ Tax on nitrogen fertiliser.
The recovery of farm income in BAL-scenario is clearly policy-driven whereas in other scenarios farm income and agri-environmental payments are constantly decreasing in 2008-2020. It seems that the economies of scale and specialisation effects in animal production are stronger than policy incentives to reduce local $\mathrm{P}$ balances in the BAL scenario where equal weights were given for decreasing both $\mathrm{N}$ and $\mathrm{P}$ surpluses. BAL-policy and its balance-based targets seem to be relatively cost-efficient in abatement of both nutrients, on the average (Table 4).

Table 4. Discounted income stream (€ million), income loss compared to the BASE scenario, and budget expenditure, in total in 2008-2020 (discount rate $=1.8 \%$ ), as well as relative changes in nitrogen $(\mathrm{N})$ and phosphorus $(\mathrm{P})$ balances in $2005-2020$. BASE $=$ No changes in agricultural policy after 2007; NDEC1 = Full decoupling of national support; NDEC2 = Partial decoupling of national support; BAL = payments for reduced nutrient surpluses; FTAX = Tax on nitrogen fertiliser.

\begin{tabular}{|c|c|c|c|c|c|}
\hline$€$ million & BASE & NDEC1 & NDEC2 & BAL & FTAX \\
\hline Farm income & 10781 & 11210 & 10816 & 9987 & 10441 \\
\hline Income loss & & -429 & -35 & 794 & 340 \\
\hline Expenditure on agri-environmental support & 2931 & 2607 & 2721 & 2409 & 2600 \\
\hline Expenditure on all agricultural supports & 19102 & 18949 & 18810 & 18256 & 18713 \\
\hline Change in overall $\mathrm{N}$ balance & -9.8 & -30.3 & -18.0 & -44.4 & -32.0 \\
\hline Change in overall $\mathrm{P}$ balance & -16.8 & -42.3 & -27.6 & -35.9 & -35.2 \\
\hline $\begin{array}{l}\text { Expenditure on agri-environmental support per } \% \\
\text { change in overall } \mathrm{N} \text { balance }(€ / \%)\end{array}$ & 300 & 86 & 151 & 54 & 81 \\
\hline $\begin{array}{l}\text { Expenditure on agri-environmental support per } \% \\
\text { change in overall } \mathrm{P} \text { balance }(€ / \%)\end{array}$ & 175 & 62 & 99 & 67 & 74 \\
\hline $\begin{array}{l}\text { Expenditure on agricultural supports per } \% \text { change in } \\
\text { overall } \mathrm{N} \text { balance }(€ / \%)\end{array}$ & 1956 & 626 & 1046 & 411 & 585 \\
\hline $\begin{array}{l}\text { Expenditure on agricultural supports per \% change in } \\
\text { overall } \mathrm{P} \text { balance }(€ / \%)\end{array}$ & 1140 & 448 & 682 & 509 & 532 \\
\hline $\begin{array}{l}\text { Income loss (compared to BASE) per \% change in } \\
\text { overall } \mathrm{N} \text { balance }(€ / \%)\end{array}$ & & -14.2 & -1.9 & 17.9 & 10.6 \\
\hline $\begin{array}{l}\text { Income loss (compared to BASE) per } \% \text { change in } \\
\text { overall P balance }(€ / \%)\end{array}$ & & -10.1 & -1.3 & 22.1 & 9.7 \\
\hline
\end{tabular}




\section{Conclusions and policy implications}

Four different policy scenarios for decreasing nutrient surpluses from farmlands in Finland were analysed in this study using sector-level economic modelling. Impacts of these policy scenarios on the nutrient surpluses, agricultural production, and farm income were assessed and compared to known baseline policy including the existing reformed CAP (decoupling $90 \%$ of CAP payments in 2006), production coupled national supports and current agri-environmental policy in Finland. In the baseline scenario approximately $10 \%$ reduction is reached in the nutrient surpluses, since set-aside areas would almost double compared to 2005 level, up to $25 \%$ of the total farmland area. Production volumes of cereals are likely to decrease in baseline scenario while animal production would decrease only little. However, on actively cultivated farm land $\mathrm{P}$ surpluses are likely to increase, which requires further regulations or policy incentives if target is to reduce $\mathrm{P}$ surpluses significantly.

Our analysis makes clear that full decoupling of national support alone would bring considerable reductions in $\mathrm{P}$ and also in $\mathrm{N}$ surplus, on the average, while increasing farm income. However nutrient balances on actively cultivated land would slightly increase while set-aside areas would increase to a higher level than in baseline scenario. The payment for reduced nutrient surplus scenario with its simple measures is capable of achieving most of the reduction in $\mathrm{N}$ and $\mathrm{P}$ surpluses which take place in the full decoupling scenario. This scenario is relatively effective in reducing $\mathrm{N}$ surplus considering total farm support payments, but less efficient when considering reduction in farm income. However the payment for reduced nutrient surplus results in a negative income shock, in a substantial increase in set-aside area, reduction in the area of cereal cultivation and pork production while dairy production would remain unaffected. Thus, this scenario decreases the farm income relatively most because the targeted reduction of $\mathrm{N}$ and $\mathrm{P}$ surpluses by $50 \%$ poses significant adjustment costs for farmers. In addition to a strong negative income shock, this scenario allocates production on most competitive regions, increases nutrient surpluses there, and provides a strong incentive for other, less competitive regions not to produce even if product markets would offer incentives to produce. In fact, some fraction of feed grain is imported in this scenario even if EU level product and input prices are closely the same as in other scenarios. Consequently, payments on reduced nutrient surpluses may create significant distortions and unexpected reactions.

On the other hand, a simple tax on $\mathrm{N}$ fertiliser, keeping production coupled national supports in place, seems to result in a significant $30-32 \%$ reductions in $\mathrm{N}$ and $\mathrm{P}$ surpluses with relatively small effects on production volumes and budgetary outlays when tax revenues are taken into account. Nevertheless, the $\mathrm{N}$ tax is relatively less effective in terms of farmers' abatement costs compared to decoupling and reduced nutrient surplus scenarios. However, it is remarkable that the $\mathrm{N}$ fertiliser tax option decreases $\mathrm{N}$ and $\mathrm{P}$ surpluses almost to the extent of the full decoupling option. Hence, taking into account the collected tax revenue for government, one could conclude that the overall effectiveness of the $\mathrm{N}$ fertiliser tax option in decreasing $\mathrm{N}$ and $\mathrm{P}$ surpluses is relatively close to that of the full decoupling option. The problem with the $\mathrm{N}$ tax is the negative impact on farm income compared to the full decoupling scenario, but still the discounted stream of farm income 2008-2020 is relatively small compared to the base scenario level.

We conclude that full decoupling of national support would be the most effective in reducing $\mathrm{P}$ surpluses while payment for reduced nutrient surplus performed best with respect to $\mathrm{N}$ surplus. Economic performance (farmers' compliance cost per \%-reduction of $\mathrm{N}$ or $\mathrm{P}$ surplus) of full and partial de-coupling of national support is clearly better than that of specialised agri-environmental policy instruments, because both decoupling scenarios result in the increase of farmers' income in comparison to base scenario, and thus farmers' abatement costs are in fact negative in these two cases. However, if decoupling of production 


\section{Lehtonen et al. Economic and environmental performance of policy measures}

linked supports were made in the context of large scale trade liberalisation (Lehtonen et al. 2005) the environmental benefits of decoupling may not be that obvious. Decoupling in the context of trade liberalisation and/or decreasing support levels per hectare or decreasing crop prices may lead to decreasing crop production which may lead to increasing feed grain imports. In such a case nutrient balances may even increase due to decoupling, especially if meat prices remain strong. Hence the decoupling provides environmental benefits if other changes in the policy and markets do not lead to more intensive animal production. Moreover, we need to be aware of the fact that decoupling alone may not ensure environmental benefits on each and every region since animal production may still expand and intensify in few relatively competitive regions despite decoupling, if no environmental policy measures decelerate the intensification.

There are some caveats and shortcomings in this study that need special emphasis in future studies. For example, changing cultivation practices and tillage methods, such as the increasingly adopted no-till, may have major impacts that are not taken into account in this study. In addition, it should be noted that the above results depend on the environmental cross-compliance requirement of keeping the land in good agricultural condition. Without this requirement, the decoupling of support payments may lead to land abandonment. A related challenge in agri-environmental policy design is how to avoid large reductions in the supply of domestic agricultural products and yet still promote green set-aside and decreases in nutrient surpluses. Large drops in agricultural production may have large economic and social consequences which very likely lead to the land being abandoned.

Acknowledgements. The authors thank two reviewers and the editor for their invaluable comments.

Disclaimer. Views expressed are those of the authors and not necessarily those of the OECD or its Member countries.

\section{References}

Abrahams, N.A. \& Shortle, J.S. 2004. The Performance of Compliance Measures and Instruments for Nitrate Nonpoint Pollution Control Under Uncertainty and Alternative Agricultural Commodity Policy Regimes. Agricultural and Resource Economics Review 33: 79-90.

Armington, P., 1969. A Theory of Demand for Products Distinguished by Place of Production. IMF Staff Papers 16: 159-178.

Bäckman, S., Vermeulen, S. \& Taavitsainen, V-M. 1997. Longterm fertilizer field trials: comparison of three mathematical response models. Agricultural and Food Science in Finland 6:151-160.

Cox T.L. \& Chavas J.-P. 2001. An interregional analysis of price discrimination and domestic policy reform in the US dairy sector. American Journal of Agricultural Economics 83: 89-106.

Dewbre, J, Anton, J. \& Thompson, W. 2001. The transfer efficiency and trade effects of direct payments. American Journal of Agricultural Economics 83: 1204-1214.

Ekholm, P., Granlund, K., Kauppila, P., Mitikka, S., Niemi, J., Rankinen, K., Räike, A. \& Räsänen, J. 2006. Influence of EU policy on agricultural nutrient losses and state of receiving surface waters in Finland. Agricultural and Food Science 16: 282-300.

European Commission 2003. Mid-Term Review of the Common Agricultural Policy. July 2002 Proposals. Impact Analyses. February 2003. Directorate-General for Agriculture. http:// europa.eu.int/comm/agriculture/publi/reports/mtrimpact/ rep en.pdf. Cited June 132007.

Granlund, K., Räike, A., Ekholm, P. \& Rekolainen, S. 2005. Assessment of water protection targets for agricultural nutrient loading in Finland. Journal of Hydrology 304: 251-260.

Griffin, R.C. \& Bromley, D. W. 1982. Agricultural runoff as a nonpoint externality: a theoretical development. American Journal of Agricultural Economics 70: 37-49.

Helin, J., Laukkanen, M. \& Koikkalainen, K. 2006. Abatement costs for agricultural nitrogen and phosphorus loads: a case study of crop farming in south-western Finland. Agricultural and Food Science 15: 351-374.

Huang,W. \& LeBlanc, M. 1994. Market-based incentives for addressing non-point water quality problems: a residual nitrogen tax approach. Review of Agricultural Economics, 16: 427-440.

Iho, A. 2005. Does scale matter? Cost-effectiveness of agricultural nutrient abatement when target level varies. Agricultural and Food Science 14: 277-292.

Johansson, R.C. \& Kaplan, J.D. 2004. A carrot-and-stick approach to environmental improvement: marrying agri-environmental payments and water quality regulations. Agricultural and Resource Economics Review 33: 91-104.

Koikkalainen, K. \& Lankoski, J. 2005. Maatalouden ympäristötuen taloudellinen merkitys tukialueittain ja tuotantosuunnittain vuosina 2000 ja 2001. In: Turtola, E. \& Lemola, R. (eds). Maatalouden ympäristötuen seuranta MYTVAS 2. Agrifood Research Reports 59. Jokioinen, Finland: MTT Agrifood Research Finland. p. 140-157.

Lankoski, J. \& Ollikainen, M. 1999. The environmental effectiveness of alternative agri-environmental policy reforms: theoretical and empirical analysis. Agricultural and Food Science in Finland 8: 321-331.

Lehtonen, H. 2001. Principles, structure and application of dynamic regional sector model of Finnish agriculture. PhD thesis, Systems Analysis Laboratory, Helsinki University of Technology. Agrifood Research Finland, Economic Research (MTTL). Publ. 98. 264 p. 


\section{AGRICULTURAL AND FOOD SCIENCE}

Vol. $16(2007): 421-440$

Lehtonen, H. 2004. Impacts of de-coupling agricultural support on dairy investments and milk production volume in Finland. Acta Agriculturae Scandinavica, Section C: Food Economics, 1: 46-62.

Lehtonen, H., Aakkula, J. \& Rikkonen, P. 2005. Alternative Policy Scenarios, Sector Modelling and Indicators: A Sustainability Approach", Journal of Sustainable Agriculture, Vol. 26(4) 2005, p. 63-93.

Lehtonen, H., Bärlund, I. Tattari, S. \& Hilden M. 2007. Combining dynamic economic analysis and environmental impact modelling: Addressing uncertainty and complexity of agricultural development, Environmental Modelling \& Software 22, 5: 710-718

Lips, M. \& Rieder, P. 2005. Abolition of Raw Milk Quota in the European Union: A CGE Analysis at the Member Country Level. Journal of Agricultural Economics. Vol. 56, Number 1 (March 2005). p 1-17.

Mapp, H.P., Bernardo, D.J., Sappagh, G.J., Geleta, S. \& Watkins, K.B. 1994. Economic and environmental impacts of limiting nitrogen use to protect water quality: a stochastic regional analysis. American Journal of Agricultural Economics 76: 889-903.

Niemi, J. \& Ahlstedt, J. (eds.) 2005. Finnish Agriculture and Rural Industries 2005. Helsinki: MTT Agrifood Research Finland. $94 \mathrm{p}$

Niemi, J. \& Ahlstedt, J. (eds.) 2006. Finnish Agriculture and Rural Industries 2006. Helsinki: MTT Agrifood Research Finland. $96 \mathrm{p}$.

Pykälä, J. 2000. Mitigating human effects on European biodiversity through traditional animal husbandry. - Conservation Biology 14: 705-712.

Pro Agria 2005. Production results from dairy farms. Central Union of Rural advisory Centres in Finland. Cited 24.11.2006. Available on the internet http://www.proagria.fi/palvelut/ tuotantotulokset/maito.asp

Rankinen, K., Salo, T., Granlund, K. \& Rita, H. Simulated nitrogen leaching, nitrogen mass balances and their correlation on four farms in south-western Finland during the period 2000-2005. Agricultural and Food Science 16: 287-406.

Ribaudo, M., Horan, R. \& Smith, M. 1999. Economics of Water Quality Protection From Nonpoint Sources: Theory and Practice. Resource Economics Division, Economic Research Service, U.S. Department of Agriculture. Agricultural Economic Report 782. 120 p.

Sairanen, A., Nousiainen, J., \& Khalili, H. 1999. Korkean väkirehumäärän vaikutus maitotuotokseen ja tuotannon kannattavuuteen. Poster paper (P7) presented in Agro-Food '99 in February 2-4 1999, Tampere. (In Finnish)
Sairanen, A., Khalili, H. \& Nousiainen, J. 2003. Milk yield responses to concentrate supplementation on pasture. In: Niemeläinen, O. \& Topi-Hulmi, M. (eds.). Proceedings of the NJF's 22nd congress 'Nordic Agriculture in Global Perspective', July 1-4, 2003, Turku, Finland. Jokioinen: MTT Agrifood Research Finland, NJF. [p. 23] Cited 24.11.2006. Available on the internet: http://portal.mtt.fi/pls/portal30/docs/ folder/agronet/yhteiset hankkeet/njf/njf2003/2.pdf

Salo, T. \& Turtola, E. 2006. Nitrogen balance as an indicator of nitrogen leaching in Finland. Agriculture, Ecoystems and Environment 113: 98-107.

Shortle, J.S. \& Dunn, J. W. 1986. The relative efficiency of agricultural source water pollution control policies. American Journal of Agricultural Economics 68: 668-677.

Segerson, K. 1988. Uncertainty and incentives for nonpoint pollution control. Journal of Environmental Economics and Management 15: 87-98.

Statistics Finland 1995. Maatilatalouden yritys- ja tulotilasto 1994 (Business and Income Statistics of Farming). Finnish Official Statistics. Agriculture and Forestry 1995:8. 64 p.

Statistics Finland 2004. Maatilatalouden yritys- ja tulotilasto 2001 (Business and Income Statistics of Farming). Finnish Official Statistics. Agriculture, Forestry and Fishery 2004:54. 63 p.

Tiainen, J. \& Pakkala, T. 2000. Population changes and monitoring of farmland birds in Finland. In: Linnut-vuosikirja 1999. BirdLife Suomi. Helsinki, Finland. p. 98-105.

Tiainen, J. \& Pakkala, T. 2001. Birds. In: Pitkänen, M. and Tiainen, J. (eds.). Biodiversity of Agricultural Landscapes in Finland. BirdLife Finland Conservation Series (No3.). Helsinki, Finland. p.33-50.

Tiainen, J., Kuussaari, M., Laurila, I.P. \& Toivonen, T. (eds) 2004. Elämää pellossa - Suomen maatalousympäristön monimuotoisuus. Edita Publishing Oy, Helsinki. 366 p.

TIKE 2007. Matilda Information Service of Agricultural Statistics in Finland. http://matilda.mmm.fi (cited June 13 2007)

Uusitalo, R., Turtola, E., Grönroos, J., Kivistö, J., Mäntylahti, V., Turtola, A., Lemola, R. \& Salo, T. 2007. Finnish trends in phosphorus balances and soil test phosphorus. Agricultural and Food Science 16.: 301-316.

Valpasvuo-Jaatinen, P., Rekolainen, S. \& Latostenmaa, H. 1997 Finnish agriculture and its sustainability: environmental impacts. Ambio 26, 448-455.

Vatn, A., Bakken, L.R., Lundeby, H., Romstad, E. \& Rorstad P.K. 1997. Regulating nonpoint source pollution from agriculture: an integrated modelling analysis. European Review of Agricultural Economics 24: 207-229.

Ylätalo, M. (ed.) 1996, Maatalousyritysten sopeutuminen EU:ssa vallitseviin hintasuhteisiin. Helsingin yliopisto, Taloustieteen laitos, Maatalousekonomia. Julkaisuja 12. Helsinki. 258 p. 


\title{
SELOSTUS
}

\section{Vaihtoehtoisten politiikkatoimenpiteiden tehokkuus Suomen maatalouden ravinneylïäämien vähentämisessä}

\author{
Heikki Lehtonen, Jussi Lankoski ja Kauko Koikkalainen \\ MTT Taloustutkimus
}

Tässä artikkelissa tarkastellaan maatalouden typpi- ja fosforiylijäämien vähentämiseen tähtäävien politiikkavaihtoehtojen tehokkuutta talouden ja ympäristön kannalta. Arvioitavat politiikkatoimenpiteet ovat: (i) typpilannoitevero, (ii) typpi- ja fosforitaseisiin perustuva, ravinneylijäämän pienentämiseen myönnettävä tuki, (iii) kansallisen tuen osittainen irrottaminen tuotannosta ja (iv) kansallisen tuen täydellinen irrottaminen tuotannosta. Vaihtoehtoja analysoitiin Suomen maataloussektoria kuvaavalla dynaamisella ja alueellisella sektorimallilla (DREMFIA).

Yksikään politiikkavaihtoehto ei ollut ympäristön kannalta tehokkain sekä typen että fosforin ylijäämän vähentämisessä. Kansallisen tuen täydellinen irrottaminen tuotannosta vähensi eniten fosforiylijäämiä, kun taas ravinneylijäämän pienentämisestä maksettava tuki oli tehokkain typpiylijäämien vähentämisessä. Politiikkavaihtoehtojen taloudellista tehokkuutta arvioitiin käyttäen kriteerinä keskimääräisiä kustannuksia, joita viljelijälle koitui ravinneylijäämän vähentämisestä. Mo- lemmat kansallisen tuen tuotannosta irrottavat vaihtoehdot olivat taloudellisesti selvästi tehokkaampia kuin varsinaiset ympäristöpolitiikan ohjauskeinot, eli typpivero ja ravinneylijäämän pienentämiseen myönnettävä tuki.

Tutkimuksemme osoittaa, että ympäristöohjauskeinojen tehokkuus riippuu paljolti siitä, millaisessa maatalouspolitiikan kokonaisuudessa ne pannaan toimeen. Vastakkaissuuntaisten kannustimien vuoksi tuotantoon sidotut tulotuet heikentävät ympäristöohjauskeinojen tehokkuutta. Niinpä maatalouden tulotuet tulisi ensin irrottaa tuotannosta ja tämän jälkeen kohdistaa ympäristöohjaus tehokkaammin alueellisten ympäristöherkkyyksien mukaan. Kansallisen tuen täydellinen irrottaminen tuotannosta johtaisi kuitenkin kotieläintuotannon selvään vähenemiseen toisin kuin muut tarkastellut vaihtoehdot. Ilman muuta ympäristöohjausta kansallisen tuen irrotus voi myös johtaa tuotannon ja ravinnetaseiden kasvuun vahvoilla tuotantoalueilla. 